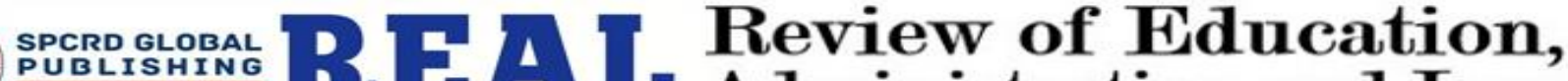 Administration and Law \\ Journal homepage: http://real.spcrd.org ISSN (Print): 2708-1788 \\ ISSN (Online): 2708-3667
}

\section{Nexus among Trust, Job Satisfaction, and Affective Organizational Commitment: A Developing Country Perspective}

\author{
${ }^{a}$ Atif Ali Gill, ${ }^{\mathrm{b}}$ Riaz Hussain Ansari, ${ }^{\mathrm{c}}$ Muhammad Waseem Tufail \\ ${ }^{a}$ Faculty Department of Business Administration, University of Sahiwal, Pakistan \\ Email: atifali@uosahiwal.edu.pk \\ ${ }^{\mathrm{b}}$ Faculty Department of Business Administration, University of Sahiwal, Pakistan \\ Email: riazhussain@uosahiwal.edu.pk \\ ${ }^{c}$ Assistant Professor, Department of Applied Psychology, University of Sahiwal, Pakistan \\ Email: waseemtufail@uosahiwal.edu.pk
}

\begin{tabular}{ll}
\hline ARTICLE DETAILS & ABSTRACT \\
\hline History: & The organizational commitment of employees plays a vital role in the \\
Accepted o5 March 2021 & success of any business. In the era of competition, companies are \\
Available Online March 2021 & struggling to retain the employees committed to the organizations. \\
& There is a scarcity of research to investigate the factors that influence \\
& effective organizational commitment in a developing country. The \\
Keywords: & researcher conducted a survey to collect data from employees working in \\
Affective Organizational & the banking sector of Pakistan. The present study utilized the \\
Commitment, Job Satisfaction, & convenience sampling method to get responses. A total of 30o \\
Trust, Banking Sector, & questionnaires were distributed, from which 215 responses were \\
Developing Country, Social & received, where 15 questionnaires were found partially filled, which were \\
Exchange Theory & discarded for further analysis. The 2oo questionnaires proceeded for \\
& statistical analysis using the partial least square structural equation \\
JEL Classification: & modeling (PLS-SEM) technique. The software of SmartPLS ver 3.o was \\
D23, J28, G24, G29 & used to analyze the significance of hypotheses. Current research revealed \\
& the significant relationship between trust and affective commitment \\
mediated through job satisfaction. The present study provides several & theoretical and practical implications by extending social exchange \\
theory and delivering guidelines to banks' human resource departments & to build trust among employees, and gauging job satisfaction to increase \\
& affective organizational commitment.
\end{tabular}

(C) 2021 The authors. Published by SPCRD Global Publishing. This is an open access article under the Creative Commons AttributionNonCommercial 4.0

Corresponding author's email address: atifali@uosahiwal.edu.pk

\section{Introduction}

Economic reforms and intense competition in the business world transform the overall industry structure and workforce behaviors within the organizations. Organizations are trying to handle the resources efficiently to get a competitive advantage (Ababneh, 2020; Yousef, 2017). The importance of the human factor gains momentum and considers a major aspect in an organization's progress 
(Agarwal \& Sajid, 2017; Malik et al., 2017). The effective utilization of human resource capital increases the competitive advantage of the firm (Nguyen et al., 2020; Vanhala et al., 2016). Employees serve as the leading asset of an organization. Retaining the best employees in an organization is becoming the need of time (Farrukh et al., 2020).

Organizational commitment has gathered attention by researchers and management to seek the appropriate methods that increase employees' attachment towards organizational effectiveness, especially in financial institutes, which serve a vital role in a country's economy (Eliyana \& Ma'arif, 2019; Zeffane \& Melhem, 2017). Affective organizational commitment is affected by the employee's Presence in an organization, leaving the workforce, the art of doing work, co-worker behavior with each other and individuals stress and families and this social behavior (Alkhateri et al., 2018). In Pakistan, banks offer different assistance types like controlling the cash flow services, deposits from savers, lending to borrowers, financing, and leasing (Khan et al., 2018).

Banks encourage corporate, government organizations by selling and giving protections in the essential market, bolster private and open partnerships in fund-raising by putting resources into the capital market. In the past, there will be an immense distinction between the administration of commercial banks and private banks in Pakistan; however, lately, these distinctions have started to evacuate, and now numerous business banks are offering significant types of the assistance of commercial banking in Pakistan.

Nowadays, the economic pressure and intense competition force the organization to manipulate the employees to retain unrealistic goals (Akgerman \& Sönmez, 2020). The job description has become very challenging, and critical performance indicators reached a very high level, affecting employees' loyalty towards organizational. At the same time, lack of trust also played a vital role in determining employee commitment (Aybar \& Marşap, 2018). Employees are less willing to share with other colleges that are building insecurity among employees.

Job satisfaction is increasing due to unrealistic goals, lack of support from the organization, and long working hours, especially in Pakistan's banking sector (Junejo et al., 2020). The banks are not following the guideline of the state bank of Pakistan. They are pressuring the employees to sit for long hours and mistrust in environment unsporting organizational culture lack of sharing with colleges decreasing the trust level of employees that ultimately affects the organization's commitment to bank employees (Asrar-ul-Haq \& Anjum, 2020). There is a dire need to assess the determinants that are affecting the corporate banking sector in Pakistan (Junejo et al., 2020; Safdar \& Liu, 2020). Those as mentioned above proposed the following research questions:

RQ1: Does trust positively influence affective organizational commitment?

RQ2: Does job satisfaction mediate the relationship between trust and affective organizational commitment?

\section{Literature Review}

\subsection{Trust and Affective Organizational Commitment}

Past studies stated that building trust in an organization helps an institute develop a strong bond between employees and their work (Nguyen et al., 2020). When employees are being treated well with complete confidence from their managers, they become personally attached to the organization and work effectively to make their organization successful (Ur Rehman et al., 2020). Scholars mentioned that employees' positive trust towards their organization makes them committed towards the 
organization. Further studies clarified that workers, including the manufacturing and service sector, respect their supervisors and loyal to the organization based on the relationship between trust and affective organizational commitment. The literature stated above proposed the following hypothesis H1: Trust positively influences affective organizational commitment.

\subsection{Trust and Job Satisfaction}

Trust is a readiness to depend on an exchange partner who has confidence (Sendjaya et al., 2019). Some researchers stated that trust is the confidence in the reliability and integrity of an exchange partner (Meng \& Berger, 2019). Trust comprises the integrity of the participant and faith in the goodwill of the partner. Further, they had also suggested that truthfulness is the belief that the partner stands by his sentence. Previous studies reported that job satisfaction depicts the level of pleasure that one feels about his profession (Hasan et al., 2018; Zeffane \& Melhem, 2017). It is a strong emotional bond to a job that often works as an influential factor. Job performance is directly consistent with success because more robust job satisfaction, higher the individual employee performance, and a person can stay positive as they can relish both personal and professional life. When workloads and stress start to deal with the individual's life, they are left emotionally depressed and agitated. Other researchers have studied that job satisfaction remains an essential variable of worker behavior and attitudes and a link for cognitive organizational engagement. The above mentioned proposed the following hypotheses:

H2: Trust positively influences job satisfaction.

\subsection{Mediating Role of Job Satisfaction}

Job satisfaction reflects the employees' positive behavior towards the institutions and commitment towards their organizations (Uzair et al., 2017). Past studies witnessed that highly motivated employees are more loyal to their companies (Al-dalahmeh et al., 2018). A strong relationship with an organization based on trust ultimately affects the job satisfaction of employees. The optimistic and direct effect of the company stems from the foundation of trust. Managers show confidence in their employees, positively affect their behavior and outcome activities by gaining trust. The increase in employees' trust in an organization leads to improved affective commitment mediated through job satisfaction (Jiang et al., 2017). Hence following hypotheses proposed as follows:

H3: Job satisfaction significantly affects affective organizational commitment.

H4: Job satisfaction plays a mediating role between trust and affective organizational commitment.

\subsection{Social Exchange Theory}

Social exchange theory is one of the most potent conceptual philosophies in organizational behavior (Harden et al., 2018). Despite its effectiveness, theoretical uncertainty persists within the theory. Social exchange theory has been used extensively by marketing scholars to explain industry-tobusiness relationship exchange (Chernyak-Hai \& Rabenu, 2018). Despite its shortcomings as an illustrative theoretical mechanism, there is no recent literature review that outlines the theory's fundamental principles and its theoretical limitations (Cropanzano et al., 2017). Social exchange theory is a concept based on the relationship between people creates value-benefit analysis. The present study's research framework is based on the social exchange theory, as shown in Figure 1. 


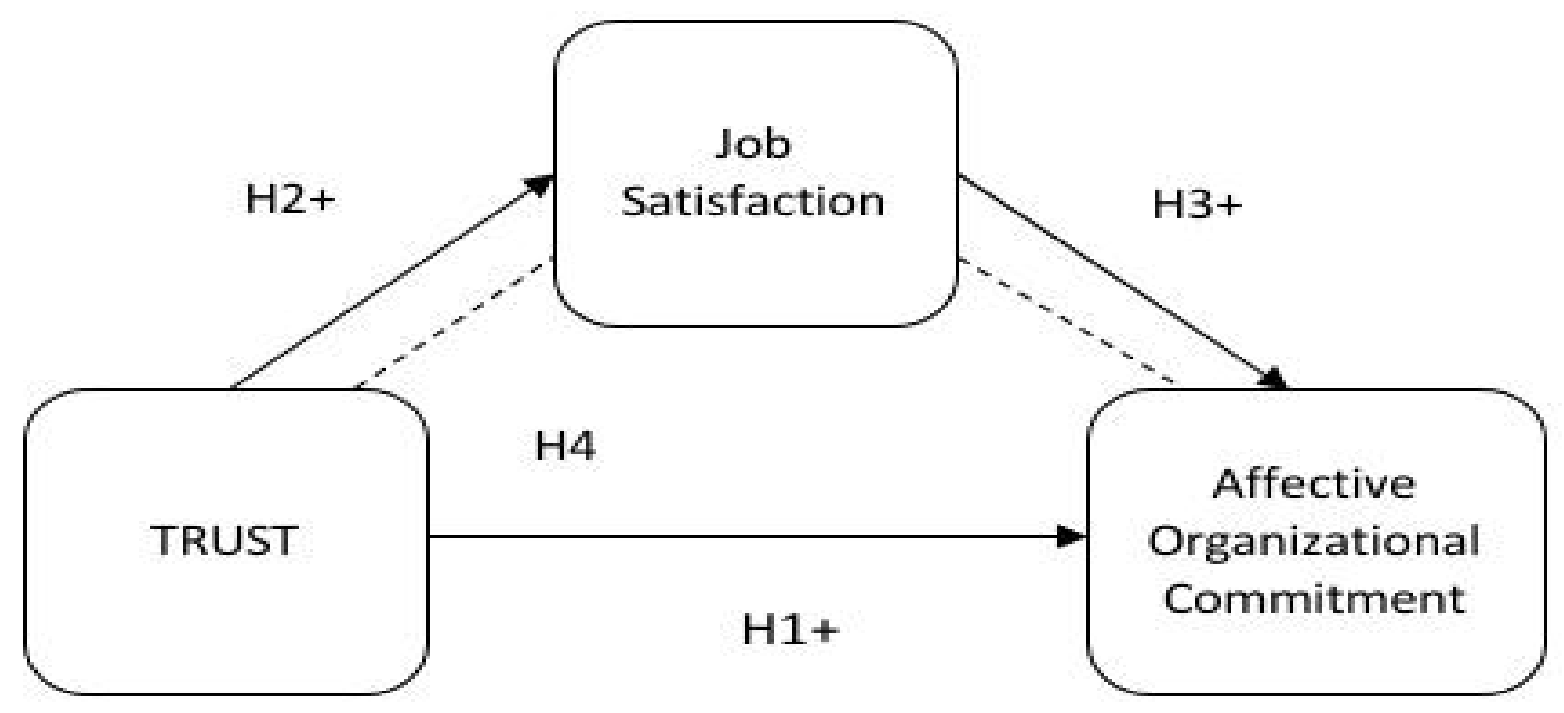

Figure 1: Theoretical framework

\section{Methodology}

\subsection{Data collection}

A survey method was used to collect data from respondents. The closed-ended questionnaire was adopted through literature, as shown in Table 1. The population was comprised of employees working in the banking sector of Pakistan. Convenience sampling was adopted to gather responses. The unit of analysis was individual. A five-point Likert scale was used for the measurement of items. A total of 300 questionnaires were distributed among respondents where only 215 received back. The 15 questionnaires were partially foiled that were discarded for further statistical analysis. The structural equation modeling technique was performed on 200 responses.

Table 1: Measurement of items

\begin{tabular}{|l|l|l|l|}
\hline Variables & Items & CR & AVE \\
\hline Trust & 11 & .87 & .91 \\
\hline Job satisfaction & 15 & .90 & .91 \\
\hline $\begin{array}{l}\text { Affective organizational } \\
\text { Commitment }\end{array}$ & 8 & .87 & .92 \\
\hline
\end{tabular}

Note: $\mathrm{CR}=$ Composite reliability, $\mathrm{AVE}=$ Average variance extracted

\subsection{Statistical technique and tools}

Partial least squares structural equation modeling (PLS-SEM) technique was used to analyze data (Sarstedt et al., 2017). The SmartPLS 3.0 software was used to test the hypotheses statistically. A two-stage analysis approach was followed, first measurement model assessment and second stage structural model assessment (Hair et al., 2017). The current study applied the bootstrapping procedure to determine mediation analysis (Preacher \& Hayes, 2004). Normalization of data is not a pre-requisite in PLS-SEM (Hair et al., 2013). It relies on bootstrapping for checking the significance of path coefficients.

\section{Data Analysis and Findings}




\subsection{Respondents Profile}

Respondents' profile represented that almost the same number of males (55.9\%) and females (43.9\%) participated in the study. While in education, it shows most respondents were having a Master's degree (69.3\%). The age variable depicted that employees who responded to the questionnaires were between the 20-30 years bracket (84.7\%). The experience variable shows that most employees were having experience between 1 to 3 years $(40.6 \%)$. The employees from the bank of Punjab have responded most by $57.4 \%$ of the total.

Table 2: Demographic profile of respondents

\begin{tabular}{|l|l|l|}
\hline Demographic variables & Frequency & Percentage \\
\hline Gender & & \\
\hline Male & 113 & $55.9 \%$ \\
\hline Female & 87 & $43.9 \%$ \\
\hline Education & & \\
\hline Intermediate & 11 & $5.4 \%$ \\
\hline Graduation & 46 & $22.69 \%$ \\
\hline Master & 140 & $69.3 \%$ \\
\hline PhD & 3 & $1.5 \%$ \\
\hline Age & & \\
\hline $20-30$ years & 171 & $84.7 \%$ \\
\hline 31-40 years & 26 & $12.9 \%$ \\
\hline 41 years and Above & 3 & $1.5 \%$ \\
\hline Experience & & \\
\hline $1-3$ years & 82 & $40.6 \%$ \\
\hline 3-5 years & 64 & $31.7 \%$ \\
\hline 5-10 years & 25 & $12.4 \%$ \\
\hline 10 years and above & 23 & $15.3 \%$ \\
\hline Banks & & \\
\hline Bank of Punjab & 116 & $57.4 \%$ \\
\hline Habib Bank limited & 23 & $11.4 \%$ \\
\hline Bank Al Habib Limited & 23 & $11.4 \%$ \\
\hline Meezan Bank & 2 & $1.0 \%$ \\
\hline United Bank limited & 2 & $1.0 \%$ \\
\hline Faysal Bank & 10 & $5.0 \%$ \\
\hline Submit Bank & 19 & $9.4 \%$ \\
\hline Allied Bank & 2 & $1.0 \%$ \\
\hline Silk Bank & 3 & $1.5 \%$ \\
\hline & & \\
\hline
\end{tabular}

\subsection{Assessment of Measurement Model}

Assessment of measurement model is the first step while analyzing the data in SmartPLS Software (Hair et al., 2014). The outer model/ measurement model indicates how the items are related to their constructs, respectively. It helps researchers ensure the validity and reliability of constructs. The measurement model uses different measures as composite reliability (CR), average variance extracted (AVE), and item loadings to evaluate the indicator reliability, internal consistency, and discriminant validity (Hair Jr et al., 2020). The measurement model of the current study shown in 
Figure 2 using PLS algorithm in Smart PLS 3.0.

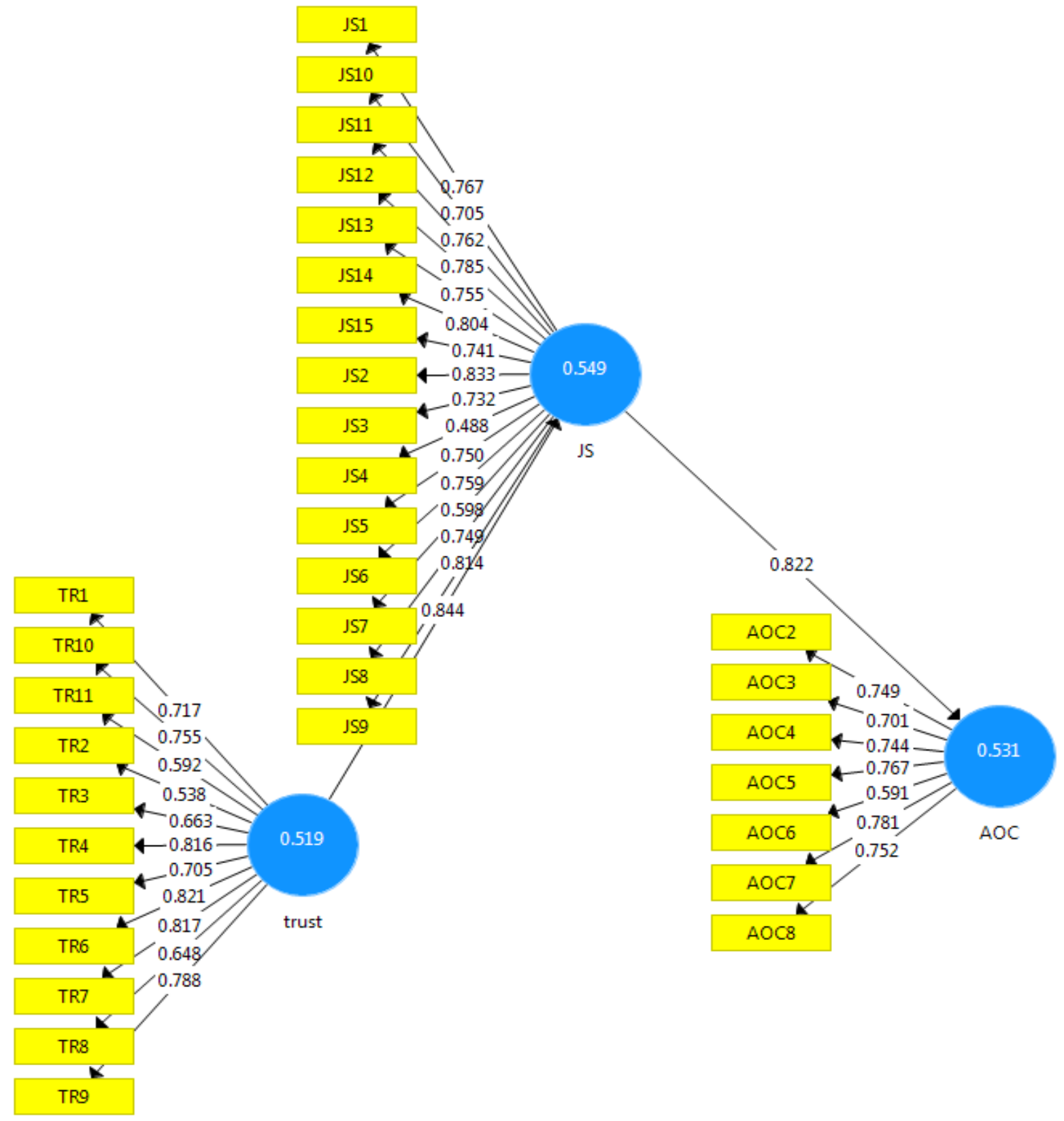

Figure 2: The Assessment MeAsurements

\subsection{Internal Consistency, Reliability, and Convergent Validity}

The internal consistency of items examined through measurement model represented by loadings which should be greater than 0.4 (Hair Jr et al., 2020), as shown in Table 3 of each item of three constructs trust, job satisfaction, and affective organizational commitment. The Composite reliability depicts the reliability of constructs greater than 0.7 (Hair et al., 2014), as shown in Table 3, while the average variance extracted (AVE) reflects the convergent validity, which should be more than 0.5 (Hair et al., 2017). When there is a problem with AVE, fewer than 0.5 AVE should be discarded. AVE's values for all the constructs were more than 0.5 (Trust $=0.519$, Job satisfaction $=0.549$, Affective organizational commitment $=0.531)$.

Table 3: Indicator Loadings, Internal Consistency Reliability, and Convergent Validity 


\begin{tabular}{|c|c|c|c|c|}
\hline Constructs & Items & Loadings & $\mathrm{CR}$ & AVE \\
\hline \multirow[t]{7}{*}{$\begin{array}{l}\text { Affective } \\
\text { Commitment }\end{array}$} & $\mathrm{AOC} 2$ & \begin{tabular}{l|l|} 
& 0.749
\end{tabular} & 0.887 & 0.531 \\
\hline & $\mathrm{AOC}_{3}$ & 0.701 & & \\
\hline & $\mathrm{AOC}_{4}$ & 0.744 & & \\
\hline & $\mathrm{AOC}_{5}$ & 0.767 & & \\
\hline & AOC6 & 0.591 & & \\
\hline & $\mathrm{AOC}_{7}$ & 0.781 & & \\
\hline & $\mathrm{AOC} 8$ & 0.752 & & \\
\hline \multirow[t]{15}{*}{ Job Satisfaction } & JS1 & 0.767 & 0.947 & 0.549 \\
\hline & JS10 & 0.705 & & \\
\hline & JS11 & 0.762 & & \\
\hline & JS12 & 0.785 & & \\
\hline & JS13 & 0.755 & & \\
\hline & JS14 & 0.804 & & \\
\hline & JS15 & 0.741 & & \\
\hline & JS2 & 0.833 & & \\
\hline & JS3 & 0.732 & & \\
\hline & $\mathrm{JS}_{4}$ & 0.488 & & \\
\hline & $\mathrm{JS}_{5}$ & 0.750 & & \\
\hline & JS6 & 0.759 & & \\
\hline & JS7 & 0.598 & & \\
\hline & JS8 & 0.749 & & \\
\hline & JS9 & 0.814 & & \\
\hline \multirow[t]{11}{*}{ Trust } & TR1 & 0.717 & 0.921 & 0.519 \\
\hline & TR10 & 0.755 & & \\
\hline & TR11 & 0.592 & & \\
\hline & TR2 & 0.538 & & \\
\hline & TR3 & 0.663 & & \\
\hline & TR4 & 0.816 & & \\
\hline & TR5 & 0.705 & & \\
\hline & TR6 & 0.821 & & \\
\hline & TR7 & 0.817 & & \\
\hline & TR8 & 0.648 & & \\
\hline & TR9 & 0.788 & & \\
\hline
\end{tabular}

Note: $\mathrm{CR}=$ Composite reliability, AVE $=$ Average variance extracted

\subsection{Discriminant Validity}

The discriminant validity of constructs in the present study was measured through the crossloading method (Hair et al., 2013), as shown in Table 4. The values in Table 4 indicate that all three constructs, trust, job satisfaction, and affective organizational commitment, are discriminant valid.

Table 4: Cross-loadings Method

\begin{tabular}{|l|l|l|l|}
\hline & AOC & JS & Trust \\
\hline AOC2 & $\mathbf{0 . 7 4 9}$ & 0.662 & 0.630 \\
\hline
\end{tabular}




\begin{tabular}{|c|c|c|c|}
\hline $\mathrm{AOC}_{3}$ & 0.701 & 0.586 & 0.651 \\
\hline $\mathrm{AOC}_{4}$ & 0.744 & 0.619 & 0.624 \\
\hline $\mathrm{AOC}_{5}$ & 0.767 & 0.584 & 0.594 \\
\hline AOC6 & 0.591 & 0.406 & 0.434 \\
\hline $\mathrm{AOC}_{7}$ & 0.781 & 0.689 & 0.615 \\
\hline AOC8 & 0.752 & 0.593 & 0.484 \\
\hline JS1 & 0.676 & 0.767 & 0.602 \\
\hline JS10 & 0.573 & 0.705 & 0.620 \\
\hline JS11 & 0.577 & 0.762 & 0.650 \\
\hline JS12 & 0.633 & 0.785 & 0.667 \\
\hline $\mathrm{JS} 13$ & 0.704 & 0.755 & 0.525 \\
\hline JS14 & 0.697 & 0.804 & 0.615 \\
\hline JS15 & 0.559 & 0.741 & 0.638 \\
\hline JS2 & 0.706 & 0.833 & 0.639 \\
\hline $\mathrm{JS} 3$ & 0.560 & 0.732 & 0.681 \\
\hline $\mathrm{JS}_{4}$ & 0.272 & 0.488 & 0.481 \\
\hline JS5 & 0.657 & 0.750 & 0.658 \\
\hline JS6 & 0.622 & 0.759 & 0.705 \\
\hline JS7 & 0.521 & 0.598 & 0.468 \\
\hline JS8 & 0.599 & 0.749 & 0.663 \\
\hline JS9 & 0.664 & 0.814 & 0.722 \\
\hline TR1 & 0.546 & 0.613 & 0.717 \\
\hline TR10 & 0.613 & 0.619 & 0.755 \\
\hline TR11 & 0.408 & 0.409 & 0.592 \\
\hline TR2 & 0.258 & 0.418 & 0.538 \\
\hline TR3 & 0.621 & 0.522 & 0.663 \\
\hline TR4 & 0.635 & 0.722 & 0.816 \\
\hline TR5 & 0.599 & 0.562 & 0.705 \\
\hline TR6 & 0.644 & 0.722 & 0.821 \\
\hline TR7 & 0.706 & 0.725 & $\mathbf{0 . 8 1 7}$ \\
\hline TR8 & 0.546 & 0.562 & 0.648 \\
\hline TR9 & 0.618 & 0.688 & 0.788 \\
\hline
\end{tabular}

Note: $A O C=$ Affective organizational commitment, TR=Trust, JS=Job Satisfaction

\subsection{Structural Model Assessment}

After measuring the construct's reliability and validity through the measurement model, the following procedure is bootstrapping through Smart PLS (Hair et al., 2017). The inner model, also known as the structural model, indicates the significance of relationships between constructs. The structural model is present in Figure 3. 


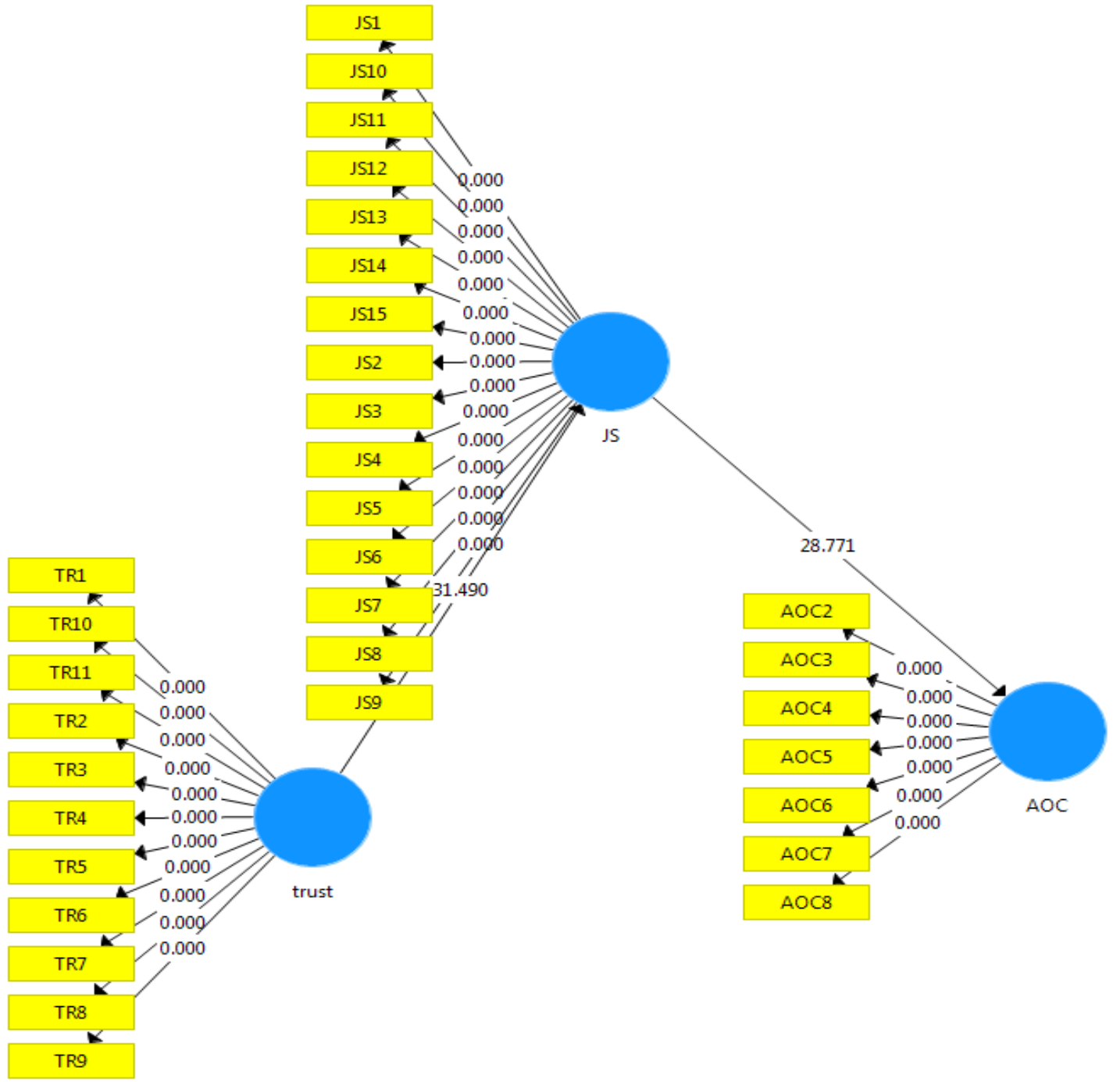

Figure 3: STRUCTURAL MODEL

\subsection{Direct hypotheses testing results}

To evaluate the direct relationships, the structural model inner model assessment was used. Path coefficient and t-values were assessed to evaluate the structural model. P-value less than 0.05 indicated the acceptance of the proposed hypothesis (Hair Jr et al., 2020). Table 5 represents the general structural model assessment results of direct effects hypotheses, and all three hypotheses $\mathrm{H} 1$, $\mathrm{H} 2$ and $\mathrm{H}_{3}$ were supported.

Table 5: Direct Hypotheses testing

\begin{tabular}{|l|l|l|l|l|}
\hline & Std Beta & Std Error & T-Value & P-Value \\
\hline H3: JS -> AOC & 0.822 & 0.029 & 28.771 & 0.000 \\
\hline H2: TR-> JS & 0.844 & 0.027 & 31.490 & 0.000 \\
\hline H1: TR -> AOC & 0.683 & 0.040 & 17.141 & 0.000 \\
\hline
\end{tabular}

Note: $\mathrm{AOC}=$ Affective organizational commitment, $\mathrm{TR}=$ Trust, JS=Job Satisfaction

\subsection{Mediation Analysis}


Mediation analysis in the current study has been performed through the bootstrapping method (Preacher \& Hayes, 2008). There is one indirect path from trust and affective organizational commitment mediated through job satisfaction. Results in Table 6 show that mediation is supported and the path between faith and affective organizational commitment mediated through job satisfaction

\section{Table 6: Mediating Hypothesis testing}

\begin{tabular}{|l|l|l|l|l|}
\hline & Std Beta & Std Error & T-vale & P-value \\
\hline H4: TR -> JS -> AOC & 0.693 & 0.040 & 17.141 & 0.0oo \\
\hline
\end{tabular}

Note: $A O C=$ Affective organizational commitment, $T R=$ Trust, JS=Job Satisfaction

\section{Discussion and conclusion}

The present research provides significant insights to examine the mediating role of job satisfaction between trust and affective organizational commitment. The four hypotheses were developed to meet the objectives of the study through literature. The statistical results reveal all three direct hypotheses were supported, and one indirect hypothesis of mediation was also supported. The first direct hypothesis was to analyze the influence of trust on affective organizational commitment. Pvalue less than 0.05 in Table 5 shows that trust has a significant positive influence on affective organizational commitment, supported by past studies (Nguyen et al., 2020). The second hypothesis was generated to analyze the effect of trust on job satisfaction, and values in Table 4 represent that trust has a significant positive influence on Job satisfaction. Hypothesis 3 was proposed to examine the effect of job satisfaction on affective organizational commitment. The numbers in Table 4 revealed that job satisfaction has a significant positive influence on affective organizational commitment. Hypothesis 4 was the indirect hypothesis to analyze the mediating impact of job satisfaction between the relationship of trust and affective organizational commitment. The statistical results in Table 5 show that the hypothesis was supported, and job satisfaction has a significant positive mediating effect between trust and affective organizational commitment supported by past literature (Saleem et al., 2020). The researchers also witnessed the same in their studies that highly motivated employees are more committed towards their organizations. The manager should arrange sessions with employees to win their trust and then improve their job satisfaction by discussing the issues with employees and resolving the matter by enhancing their satisfaction level that enhances their commitment towards the organization. The organizations have committed employees who remain more sustainable and get a competitive advantage. The present study provides numerous theoretical and practical implications by extending the social exchange theory incorporating the mediating role of job satisfaction between trust and affective organizational commitment. The researcher delivers practical guidelines to banks' administration to develop policies for committed employees by building trust and improving employees' job satisfaction.

\section{Limitations and Future predictions}

The present study only uses a quantitative method for data collection in future qualitative methods like interviews for in-depth findings. The current research considers the study population's banking sector, while another manufacturing sector can be included in further studies for more generalized results. The data collected from Pakistan representing developing countries' perspective in future comparison studies may be conducted, including a western country, to analyze the factors that affect the organizational commitment.

\section{References}


Ababneh, K. I. (2020). Effects of met expectations, trust, job satisfaction, and commitment on faculty turnover intentions in the United Arab Emirates (UAE). The International Journal of Human Resource Management, 31(2), 303-334.

Agarwal, P., \& Sajid, S. (2017). A study of job satisfaction, organizational commitment and turnover intention among public and private sector employees. Journal of Management Research, 17(3), $123-136$.

Akgerman, A., \& Sönmez, B. (2020). The relationship between trust in first-line nurse managers and organizational commitment. International Nursing Review, 67(2), 183-190.

Al-dalahmeh, M., Khalaf, R., \& Obeidat, B. (2018). The effect of employee engagement on organizational performance via the mediating role of job satisfaction: The case of IT employees in Jordanian banking sector. Modern Applied Science, 12(6), 17-43.

Alkhateri, A. S., Abuelhassan, A. E., Khalifa, G. S., Nusari, M., \& Ameen, A. (2018). The Impact of perceived supervisor support on employees turnover intention: The Mediating role of job satisfaction and affective organizational commitment. International Business Management, 12(7), 477-492.

Asrar-ul-Haq, M., \& Anjum, T. (2020). Impact of narcissistic leadership on employee work outcomes in banking sector of Pakistan. Future Business Journal, 6(1), 1-9.

Aybar, S., \& Marşap, A. (2018). The moderating role of organizational trust on the relationship between perception of organizational politics and organizational commitment: Research in Istanbul University. Journal of Business Research, 10(2), 758-782.

Chernyak-Hai, L., \& Rabenu, E. (2018). The new era workplace relationships: Is social exchange theory still relevant? Industrial and Organizational Psychology, 11(3), 456-481.

Cropanzano, R., Anthony, E. L., Daniels, S. R., \& Hall, A. V. (2017). Social exchange theory: A critical review with theoretical remedies. Academy of Management Annals, 11(1), 479-516.

Eliyana, A., \& Ma'arif, S. (2019). Job satisfaction and organizational commitment effect in the transformational leadership towards employee performance. European Research on Management and Business Economics, 25(3), 144-150.

Farrukh, M., Kalimuthu, R., Farrukh, S., \& Khan, M. S. (2020). Role of Job satisfaction and organizational commitment in Employee Loyalty: Empirical Analysis from Saudi Hotel Industry. Int. J. Bus. Psychol, 2, 1-20.

Hair, Hult, G. T. M., Ringle, C., \& Sarstedt, M. (2014). A primer on partial least squares structural equation modeling (PLS-SEM).

Hair, J., Hollingsworth, C. L., Randolph, A. B., \& Chong, A. Y. L. (2017). An updated and expanded assessment of PLS-SEM in information systems research. Industrial Management \& Data Systems, 117(3), 442-458. https://doi.org/10.1108/IMDS-04-2016-0130

Hair Jr, J. F., Howard, M. C., \& Nitzl, C. (2020). Assessing measurement model quality in PLS-SEM using confirmatory composite analysis. Journal of Business Research, 109, 101-110.

Hair, Ringle, C. M., \& Sarstedt, M. (2013). Partial least squares structural equation modeling: Rigorous applications, better results and higher acceptance. Long Range Planning, 46(1-2), 1-12.

Harden, G., Boakye, K. G., \& Ryan, S. (2018). Turnover intention of technology professionals: A social exchange theory perspective. Journal of Computer Information Systems, 58(4), 291-300.

Hasan, A., Noreen, S., \& Mohsin, M. (2018). The Relationship among Perceived Organizational Support, Trust, Job Satisfaction and Turnover Intention: A Study of Banking Sector in Pakistan. International Journal of Human Resource Studies, 8(4), 227241-227241.

Jiang, Z., Gollan, P. J., \& Brooks, G. (2017). Relationships between organizational justice, organizational trust and organizational commitment: A cross-cultural study of China, South Korea and Australia. The International Journal of Human Resource Management, 28(7), 973-1004. 
Junejo, M. A., Ashraf, M., \& Shaikh, S. (2020). Determinants of working environment and their influence on job satisfaction: Evidence from banking sector. International Journal of Experiential Learning \& Case Studies, 5(1), 100-112.

Khan, M., Sarwar, S., \& Khan, H. (2018). Impact of corporate social responsibility on job attitudes: Job satisfaction and organizational commitment of banking sector employees of Pakistan. SEISENSE Journal of Management, 1(3), 28-47.

Malik, W. U., Javed, M., \& Hassan, S. T. (2017). Influence of transformational leadership components on job satisfaction and organizational commitment. Pakistan Journal of Commerce and Social Sciences (PJCSS), 11(1), 147-166.

Meng, J., \& Berger, B. K. (2019). The impact of organizational culture and leadership performance on PR professionals' job satisfaction: Testing the joint mediating effects of engagement and trust. Public Relations Review, 45(1), 64-75.

Nguyen, T., Pham, T., Le, Q., \& Bui, T. (2020). Impact of corporate social responsibility on organizational commitment through organizational trust and organizational identification. Management Science Letters, 10(14), 3453-3462.

Preacher, K. J., \& Hayes, A. F. (2004). SPSS and SAS procedures for estimating indirect effects in simple mediation models. Behavior Research Methods, Instruments, \& Computers, 36(4), 717-731. https://doi.org/10.3758/BFo3206553

Preacher, K. J., \& Hayes, A. F. (2008). Assessing mediation in communication research. The Sage Sourcebook of Advanced Data Analysis Methods for Communication Research, 13-54.

Safdar, S., \& Liu, S. (2020). The influence of justice on commitment of Pakistani bankers: Job satisfaction as mediator. International Journal of Public Administration, 43(14), 1183-1193.

Saleem, F., Zhang, Y. Z., Gopinath, C., \& Adeel, A. (2020). Impact of servant leadership on performance: The mediating role of affective and cognitive trust. SAGE Open, 10(1), 2158244019900562.

Sarstedt, M., Ringle, C. M., \& Hair, J. F. (2017). Partial least squares structural equation modeling. Handbook of Market Research, 26(1), 1-40.

Sendjaya, S., Pekerti, A. A., Cooper, B. K., \& Zhu, C. J. (2019). Fostering organisational citizenship behaviour in Asia: The mediating roles of trust and job satisfaction. In Leading for High Performance in Asia (pp. 1-18). Springer.

Ur Rehman, K., Hafeez, I., Aslam, F., Maitlo, Q., \& Syed, A. R. (2020). The Mediating Role of Trust and Organizational Commitment in the Relationship between Strategic Human Resource Management and Knowledge Sharing. Iranian Journal of Management Studies, 13(4).

Uzair, M., Razzaq, W., Sarfraz, M., \& Nisar, Q. A. (2017). Impact of HR practices on employee loyalty and commitment: Mediating role of job satisfaction. International Journal of Management Excellence, 9(2), 1067-1073.

Vanhala, M., Heilmann, P., \& Salminen, H. (2016). Organizational trust dimensions as antecedents of organizational commitment. Knowledge and Process Management, 23(1), 46-61.

Yousef, D. A. (2017). Organizational commitment, job satisfaction and attitudes toward organizational change: A study in the local government. International Journal of Public Administration, 40(1), 77-88.

Zeffane, R., \& Melhem, S. J. B. (2017). Trust, job satisfaction, perceived organizational performance and turnover intention. Employee Relations. 